\title{
A Study of Vegetative Reproduction in Endomycopsis platypodis by Electron Microscopy
}

\author{
By N. J. W. KREGER-VAN RIJ \\ Laboratory of Bacteriology and Serology, State University, Groningen, Netherlands \\ AND M. VEENHUIS \\ Laboratory of Ultrastructural Biology, State University, Haren, Netherlands
}

(Accepted for publication 2 July 1969)

\begin{abstract}
SUMMARY
The hyphal cross-walls in Endomycopsis platypodis had dolipores and, depending on the conditions of growth, dolipores were sometimes present in the walls between budding cells also. The formation of walls, both in hyphae and between budding cells, was initiated by an electron-light primary wall. This was later thickened at both sides with electron-dense material, and the dolipore exhibited an extra swelling around the pore channel. Buds separated from their parents at the primary wall, which remained attached to the mother cell.
\end{abstract}

\section{INTRODUCTION}

The yeast species Endomycopsis platypodis Baker \& Kreger-van Rij (1964) reproduces vegetatively by the formation of round to oval cells and of branched hyphae with cross-walls. The round or oval cells may remain attached to each other forming pseudomycelium. They are also formed laterally or terminally on the hyphae, and hyphae may arise from round or oval cells. Kreger-van Rij \& Veenhuis (1969) observed plugged dolipores in the cross-walls of the hyphae. The wall between budding cells was generally of normal thickness, but occasionally swollen in the middle.

Bud formation and the formation of hyphae with cross-walls are characteristics used in yeast taxonomy. However, insufficient is known to make an absolute distinction between both forms of reproduction. Endomycopsis platypodis is suitable material for the closer examination of these forms. The present study is concerned with the formation of cross-walls and with the development of buds in this species as observed in ultrathin sections under the electron microscope.

\section{METHODS}

The type strain of Endomycopsis platypodis (CBS $4 \mathrm{I}$ I I ) was studied. In this strain the formation of a cross-wall took only about $8 \mathrm{~min}$., while the swelling of the dolipore was visible within one hr. To observe different stages of the formation of cross-walls and of dolipores, a preparation containing many growing tips of hyphae was required. A $24 \mathrm{hr}$ culture in a Petri dish with a thin layer of malt extract inoculated heavily with round cells fulfilled this requirement since, under these conditions, many cells formed hyphae. On the other hand, in a $24 \mathrm{hr}$ shaken culture in malt extract, budding cells exclusively were formed. Both cultures were prepared and incubated at $27^{\circ}$. The 
harvested cells were washed with water and, after fixation with $\mathrm{I} \cdot 5 \%$ aqueous $\mathrm{KMnO}_{4}$ solution for $20 \mathrm{~min}$. at room temperature, suspended in agar. The agar blocks were dehydrated in an acetone series and poststained with a saturated solution of uranyl acetate in $100 \%$ acetone for one $\mathrm{hr}$. After washing with acetone to remove excess uranyl acetate, the specimens were embedded in Vestopal $W$ at $60^{\circ}$, and were cut with a diamond knife on an LKB Ultrotome. The sections were poststained with lead citrate (Reynolds, I963). They were examined with a Philips EM Ioo electron microscope.

\section{RESULTS}

Formation of cross-walls in hyphae in standing culture

The beginning of cross-wall formation was observed in sections as a narrow electronlight outgrowth of the lateral wall (Pl. I, fig. I). This primary wall had a wedge-like edge in the lateral wall, which surrounded the primary wall at its base (Pl. I, fig. 2). Nothing on the outside of the lateral wall served to indicate the presence of a crosswall. The primary wall grew centripetally leaving a pore in the centre (Pl. I, fig. 3). In the next stage, the wall thickened at both sides with secondary electron-dense layers with an extra swelling around the pore. This pore, surrounded by the swelling, was the dolipore which at first formed an open connexion between the two adjacent hyphal cells (Pl. I, fig. 4), but later became plugged (Pl. I, fig. 5). Generally, from the beginning of its formation, the cross-wall tended to bulge in the direction of the hyphal tip, probably owing to a strong protoplasmic stream; at the concave side of the crosswall dense protoplasm often occurred, and at the convex side a vacuole was sometimes present.

\section{Formation of buds in shaken culture}

The first stage of bud formation observed is shown in P1. 2, fig. 6. The bud was still small; its wall arose from under the wall of the mother cell. The electron-micrographs suggest that later between the walls of mother cell and bud, an electron-light collar was formed which appeared in sections as a wedge (Pl. 2, fig. 7,8$)$. In these first stages, mitochondria and endoplasmic reticulum moved into the bud, followed by the nucleus which elongated and split on arriving at the isthmus between mother cell and bud. Thereupon, a primary electron-light wall was formed centripetally across the isthmus (P1. 2, fig. 9). Like the primary wall of the cross-walls of hyphae, this wall in a budding cell had a wedge-like edge. This edge touched the electron-light collar and thus split the original wall of the bud. The primary wall was thickened with electron-dense material at each side (PI. 2, fig. IO, I I). The bud was finally separated from the mother cell by splitting along the primary wall in such a way that this wall remained attached to the mother cell (Pl. 3, fig. I2, I3.) The rim of the bud scar consisted of the edge of the mother cell and that of the white collar. On the young bud a wide scar was visible with a vague narrow ridge. The latter constituted the breaking point between mother cell and bud. The primary wall between mother cell and bud in sections often had an undulating appearance. When the secondary wall was formed it was straight. After separation of the bud from the mother cell, both bud- and birth scars bulged outwards. 


\section{Formation of buds in standing culture}

In a standing culture, apart from hyphae, buds were formed on the round cells. The buds arose as described in the previous paragraph; at the junction between mother cell and bud they were surrounded by a two-layered collar on the mother cell. Some of the buds developed with a thin wall between mother cell and bud. Others, however, were separated from the mother cell by a wall with a dolipore and plugs (Pl. 3, fig. I4). The actual pore was sometimes a very narrow channel. These cells remained attached to each other as pseudomycelium, but sometimes there were also loose cells with a thickened scar wall, presumably resulting from the swelling of the dolipore. No trace of the channel was found.
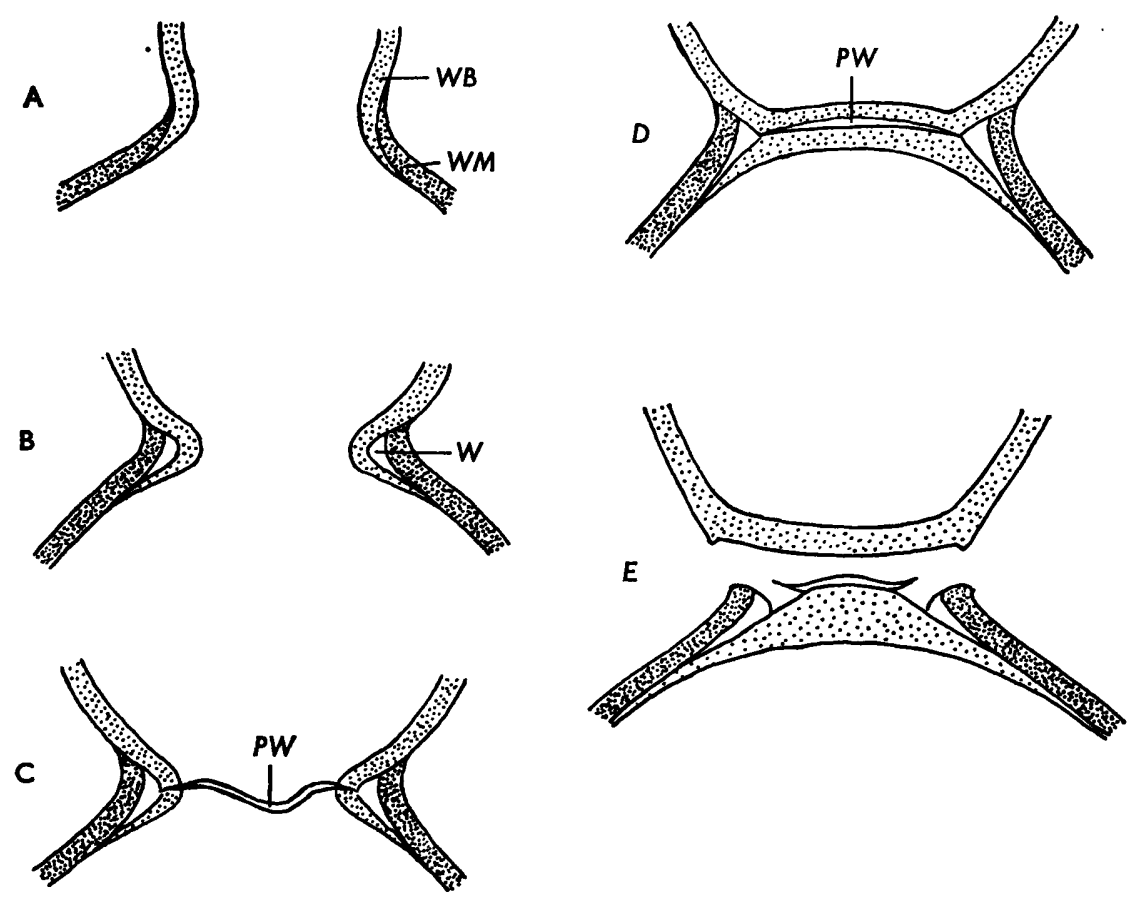

Fig. 1. Diagram of bud formation in E. platypodis. $W M=$ cell wall of mother cell, $W B=$ cell wall of bud, $W=$ electron-light collar, $P W=$ primary wall.

Hyphae arose on round cells from a narrow neck with a collar on the mother cell and were separated from the latter by a cross-wall with a dolipore in the narrow part (Pl. 3, fig. I5). A short-oval cell sometimes grew out on a wider base to form a hypha. No distinct collar was visible in this case, and the cross-wall in the hypha was formed at some distance from the mother cell (Pl. 3, fig. I6).

\section{DISCUSSION}

The development of a cross-wall with a dolipore in Endomycopsis platypodis proceeded via the formation of a primary electron-light layer. This layer was thickened with an extra swelling around the pore. In contrast with the dolipore of the Basidio- 
mycetes, no pore cap was formed, but at both sides of the pore plugs were present which were probably dilations of the endoplasmic reticulum. The plugs were formed at an early stage.

In the first stage of bud formation observed, the bud was already distinct, its wall different from that of the mother cell. No earlier stage was recognized as such, so it is not known how the wall of the mother cell was penetrated by the bud. The doublelayered elevated edge of the scar was present as a collar when the bud was still in open connexion with the mother cell. This collar was also distinct when a hypha was formed on a narrow base on a round cell. With hyphae that arose on a broad base from oval cells, the collar was indistinct or not visible at all.

Dolipores were always present in the cross-walls of the hyphae, whether from a standing malt extract culture or from the surface of an agar medium. However, in the cell walls between round or oval cells the formation of dolipores was observed in standing cultures only; in shaken cultures they did not appear. Round or oval cells often remained together as pseudomycelium and then the walls between them showed dolipores; but loose cells with thickened bud- or birth scar plugs, probably resulting from dolipores, were also observed.

Attention has been drawn above to three particular features. (I) The join between two adjacent cells was narrow or wide. It was narrow in budding, the separating wall forming in the narrow part with a collar on the mother cell at the base of the bud. The collar occurred between round or oval cells, and between hyphae and round or oval cells. A wide join between cells, without any narrowing at the junction of the lateral wall and cross-wall, was typical of hyphae. (2) A dolipore was present in the separating wall, both of hyphae and of some budding cells. (3) Complete separation of the cells at the intervening wall was only observed for round and oval cells.

These features indicate some of the differences and resemblances between hyphae and budding cells. Other aspects, such as zones of growth of the wall and the site of formation of hyphal cross-walls, have yet to be studied.

Since bud formation in ascogenous yeasts has been mainly studied in Saccharomyces cerevisiae, budding in Endomycopsis platypodis has been compared with that in Saccharomyces cerevisiae as described by others and as observed by the present authors. A similar development was found in both species which differs, however, in some respects from the recent description of $S$. cerevisiae by Marchant \& Smith (1968). In the first place, in S. cerevisiae the wall of the bud did not appear to be continuous with that of the mother cell, the wall of the bud protruding from the inside of the mother cell as is clearly shown in Pl. 3, fig. 17. However, the part of the cell wall of the bud within the mother cell was not always distinctly visible. The observation that the walls of mother cell and bud were not continuous agrees with the description of bud formation on a regenerating protoplast by Nečas \& Svoboda (1967). Secondly, in both $E$. platypodis and $S$. cerevisiae the electron-light layer of the wall between mother cell and bud was found to be the primary wall which later extended to both sides with electron-dense material (P1. 3, fig. 18). Sentandreu \& Northcote (1969) also described the formation of a primary wall which later thickened in $S$. cerevisiae. In the electron-micrographs published by Marchant \& Smith (1968) the electron-light layer was distinct, but was not described as a primary wall. Splitting of the bud from the mother cell occurred along this wall, and the electron-light layer, which was rather thin in $S$. cerevisiae, remained attached to the mother cell (Pl. 3, fig. 19). 
Houwink \& Kreger (1953) found chitin on the plug of the bud scars of baker's yeast and of Candida tropicalis; Bacon, Davidson, Jones \& Taylor (1966), after chemical and enzymatic treatment of the cells of baker's yeast, retained a residue consisting mainly of chitin and formed entirely of bud scars. These observations in connection with our findings suggest that the electron-light parts in sections of the scars may consist of chitin.

We wish to thank Dr J. A. Barnett for corrections of the English text. The first author acknowledges the hospitality of the Laboratory of Ultrastructural Biology of the State University of Groningen.

\section{REFERENCES}

Bacon, J. S. D., Davidson, E. D., Jones, D. \& TaYlor, I. F. (I966). The location of chitin in the yeast cell wall. Biochem. J. ror, $36 \mathrm{C}$.

BAKER, J. M. \& KREGER-VAN RIJ, N. J. W. (1964). Endomycopsis platypodis sp.n. (Ascomycetes): an auxiliary ambrosia fungus of Platypus cylindrus Fab. (Col. Platypodidae). Antonie van Leeuwenhoek 30, 433.

Houwink, A. L. \& KREGER, D. R. (1953). Observations on the cell wall of yeasts. An electron microscope and X-ray diffraction study. Antonie van Leeuwenhoek 19, I.

KREGER-VAN RiJ, N. J. W. \& Veenhuis, M. (1969). Septal pores in Endomycopsis platypodis and Endomycopsis monospora. J. gen. Microbiol. 57, 91.

MARChANT, R. \& Smith, D. G. (1968). Bud formation in Saccharomyces cerevisiae and a comparison with the mechanism of cell division in other yeasts. J. gen. Microbiol. 53, I63

NeČAS, O. \& SvOBODA, A. (1967). Mechanism of regeneration of yeast protoplasts. IV. Electron microscopy of regenerating protoplasts. Folia biol., Praha r3, 379.

ReYNolds, E. S. (1963). The use of lead citrate at high pH as an electron-opaque stain in electron microscopy. J. Cell Biol. 17, 208.

Sentandreu, R. \& NorthCote, D. H. (1969). The formation of buds in yeast. J. gen. Microbiol. 55, 393 .

\section{EXPLANATION OF PLATES}

Symbols: $L W=$ lateral wall, $P W=$ primary wall, $W M=$ cell wall of mother cell, $W B=$ cell wall of bud, $S=$ swelling, $P=$ plug, $N=$ nucleus, $E R=$ endoplasmic reticulum, $M=$ mitochondria. The marker represents $0.5 \mu$. All figures are made of material fixed with $\mathrm{KMnO}_{4}$ and poststained with lead.

\section{Plate I}

Longitudinal sections through hyphae of Endomycopsis platypodis.

Fig. I. Initial stage of the formation of a cross-wall. A nucleus is visible.

Fig. 2. Section through a primary wall beside the pore.

Fig. 3. shows a partly thickened primary wall with pore.

Fig. 4. Section through a cross-wall with swelling, but still without plugs.

Fig. 5 shows a completed cross-wall with dolipore and plugs.

Plate 2

Sections through yeast cells of $E$. platypodis.

Fig. 6. Early stage of bud formation. The wall of the bud arises from under the wall of the mother cell. $E R$ lies along the wall of the bud.

Figs. 7 and 8. Later stages in bud formation. Between the walls of bud and mother cell an electronlight wedge is visible. In fig. 7 mitochondria and $E R$ are present in the bud. In fig. 8 the nuclei of mother cell and bud are observed separately.

Fig. 9, Io and I I show three stages of wall formation between mother cell and bud. In fig. 9 the electron-light primary wall is visible. In fig. Io and I the wall has thickened at both sides with more electron-dense material. 


\section{Plate 3}

Fig. 12 to 16 are cells of $E$. platypodis, figs. 17 to 19 of $S$. cerevisiae.

Fig. 12 and 13 . Sections of partly and wholly detached buds. The primary wall remains attached to the mother cell. In fig. 13 the two layers of the rim of the scar on the mother cell, namely the edge of the mother cell and that of the electron-light collar, are distinctly visible. On the bud a vague rim of the birth scar is present (arrowed). Both bud and birth scars bulge outwards.

Fig. 14. Budding cells with a dolipore in the wall.

Fig. I5. Section through a round cell with a hypha arising from it.

Fig. 16. Section through an oval cell growing out with a hypha.

Fig. 17. Section through a budding cell of $S$. cerevisiae. The wall of the bud arises from under the wall of the mother cell.

Fig. 18 shows the electron-light primary wall thickened with darker material in $S$. cerevisiae.

Fig. 19. Section through a bud scar in $S$. cerevisiae showing the electron-light primary wall left on the mother cell. 

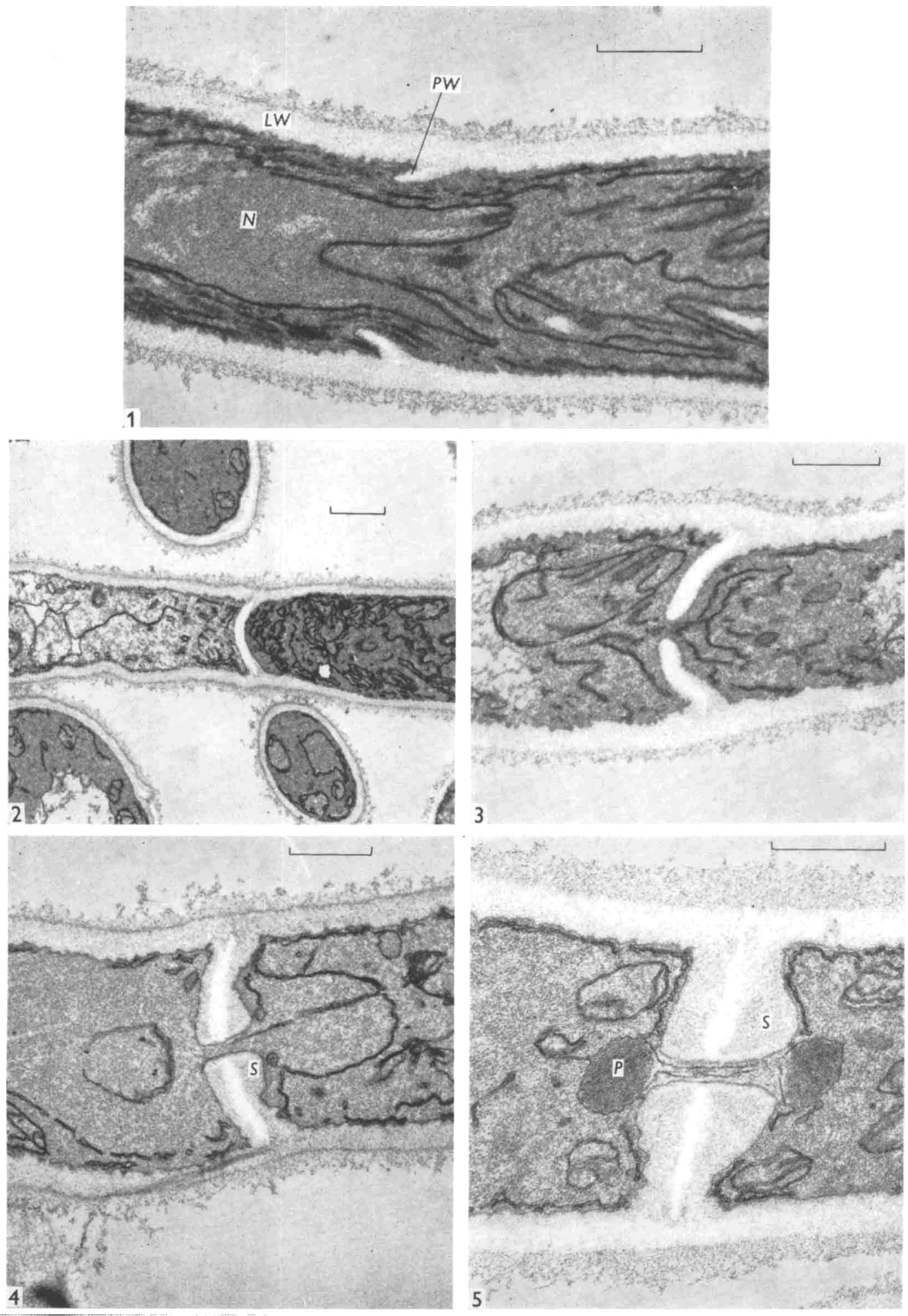

N. J. W. KREGER-VAN RIJ AND M. VEENHUIS

(Facing p. 346) 
Journal of General Microbiology, Vol. 58, No. 3

Plate 2
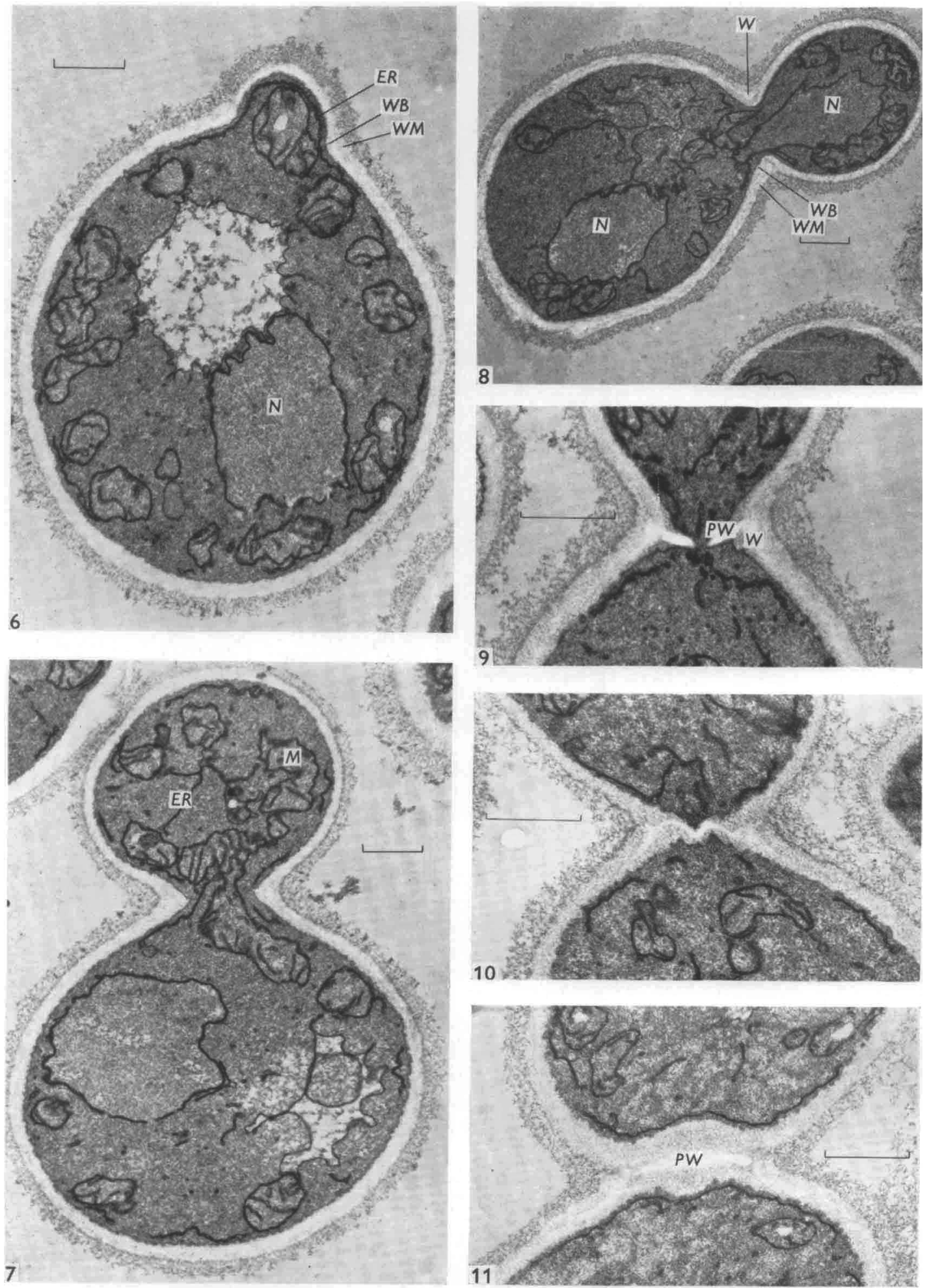

N. J. W. KREGER-VAN RIJ AND M. VEENHUIS 
Journal of General Microbiology, Vol. 58, No. 3

Plate 3
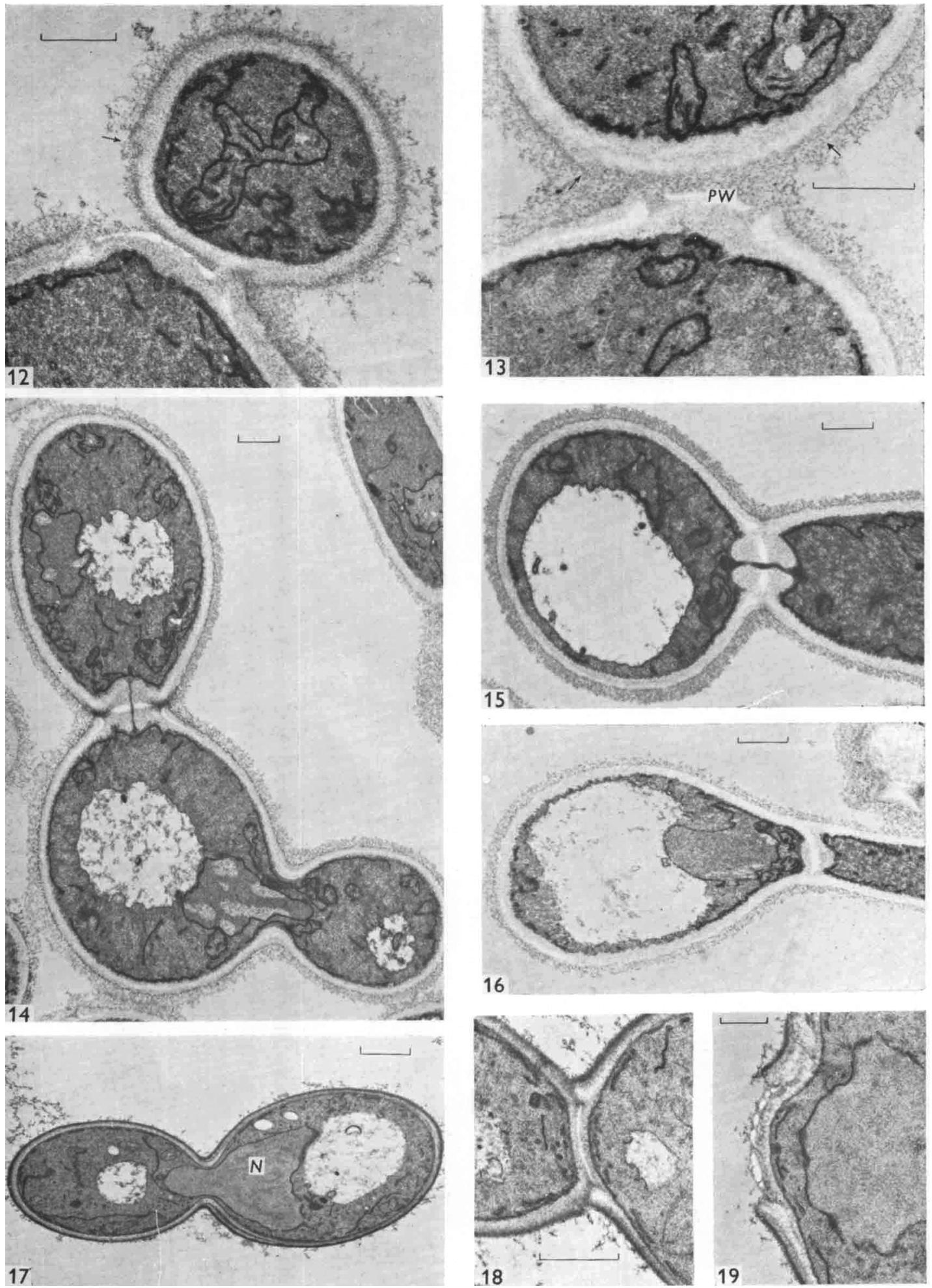

N. J. W. KREGER-VAN RIJ AND M. VEENHUIS 